\title{
FAMILY PLANNING SERVICES BY MIDWIFERY OF PRIVATE MIDWIFERY PRACTICE IN YOGYAKARTA DURING THE PANDEMIC PERIOD OF COVID-19
}

\author{
Dian Herawati ${ }^{1}$, Dina Fitriana Rosyada ${ }^{2}$, Rita Dian Pratiwi ${ }^{3}$, Estri Neni Wigati ${ }^{4}$ \\ ${ }^{1,2,3}$ Vocational School, Universitas Gadjah Mada, Street. Prof. Sudarto SH, Tembalang, Semarang, \\ Central Java, 507231, Indonesia \\ ${ }^{4}$ Master Program of Public Health, Faculty of Public Health and Nursing Universitas Gadjah Mada, Street. Imam \\ Bardjo SH No. 5 Semarang, Central Java, 50241 Indonesia
}

\begin{abstract}
Covid-19 has been declared a world pandemic by WHO. Large-scale social restrictions and community appeal to stay at home in an effort to oppose Covid-19 transmission will have an impact on the sustainability of family planning services. $54,6 \%$ of the total family services planned by midwives are conducted at the private midwifery practice. The purpose of this study was to analyze family planning service visits at the private midwifery practice in Yogyakarta. This study used quantitative descriptive method. The sample in this study is midwives who have private midwifery practice in the Special Region of Yogyakarta. The results showed that almost methods of contraception experienced a decrease in service in the private midwifery practice, except progestin injection. As many as $44,7 \%$ of midwives provide family services planned through the post placenta Intrauterine Device (IUD) was a method of contraception that was added as a post partum contraception during the main Covid-19 pandemic. Family service protocols have been implemented in the pandemic era with 19\% $78 \%$ of midwives, online, and using standard personal protective equipment. There was a decrease in family planning services by midwives in the practice of independent midwives in Yogyakarta during the Covid-19 pandemic by 13,8\% (from February to April 2020). By the decline predicted to result in a high chance of a baby boom. Midwives are expected to improve family planning services after delivery, especially the IUD, and utilize online media. Other efforts can be made through the BKKBN, namely by encouraging postpone pregnant during the Covid-19 pandemic and the existence of free family planning services so that productive partners can routinely control the use of acceptors.
\end{abstract}

Keywords: Covid-19 pandemic, family planning services, independent midwife practices

\begin{abstract}
ABSTRAK
Covid-19 telah dinyatakan sebagai pandemi dunia oleh WHO. Pembatasan sosial berskala besar dan himbauan masyarakat untuk stay at home sebagai upaya pencegahan penularan Covid-19 berdampak terhadap kelangsungan pelayanan keluarga berencana. Sebesar $54,6 \%$ dari total pelayanan keluarga berencana oleh bidan dilakukan di Praktek Mandiri Bidan. Tujuan penelitian ini adalah menganalisis kunjungan pelayanan keluarga berencana di pelayanan bidan mandiri di Yogyakarta. Jenis penelitian ini adalah analitik kuantitatif deskriptif observasional. Sampel pada penelitian ini adalah bidan yang mempunyai praktek mandiri bidan di Daerah Istimewa Yogyakarta. Hasil menunjukkan hampir semua metode kontrasepsi mengalami penurunan dalam pelayanan di praktek mandiri bidan kecuali suntik progestin. Sejumlah $44,7 \%$ bidan memberikan pelayanan keluarga berencana melalui Intrauterine Device (IUD) post placenta. Protokol pelayanan keluarga berencana telah dilakukan di era masa pandemi Covid-19 sebanyak 78,7\% bidan, yakni secara online dan pelayanan telah menggunakan standar alat pelindung diri. Terjadi penurunan pelayanan keluarga berencana oleh bidan di praktek bidan mandiri di Yogyakarta selama pandemi Covid-19 sebesar 13,8\% (mulai Februari hingga April 2020). Penurunan diprediksi dapat mengakibatkan tingginya peluang terjadi baby boom. Bidan diharapkan meningkatkan pelayanan keluarga berencana pasca persalinan terutama IUD dan memanfaatkan media online. Upaya lain dapat dilakukan melalui BKKBN yakni edukasi menunda kehamilan selama pandemi Covid-19 dan adanya pelayanan keluarga berencana secara gratis agar pasangan produktif dapat rutin dalam mengontrol penggunaan akseptor.
\end{abstract}

Kata Kunci: Pandemi covid-19, pelayanan keluarga berencana, praktik bidan mandiri

Correspondece Address: Dina Fitriana Rosyada, Vocational School, Universitas Gadjah Mada, Yogyakarta Email: dinafitriana.r@ugm.ac.id 


\section{Introduction}

Covid-19 has been declared a world pandemic by WHO. ${ }^{1}$ Indonesia also established this pandemic based on Presidential Decree No. 12 of 2020 concerning the Determination of non-natural Disasters that spread Covid-19 as a National Disaster. In the face of the Covid-19 disaster outbreak, a large-scale Social Restrictions policy was carried out and appealed to the public not to leave the house as an effort to prevent Covid-19 transmission. This condition will have an impact on the continuity of community health services, including family planning and reproductive health services. ${ }^{2}$ The family planning program helps pave the way for many subsequent health, social and economic programs. The program helps determine the feasibility and legitimacy of installing large-scale interventions aimed at goals such as improving maternal and child health, eradicating diseases, improving nutrition, increasing educational opportunities, and carrying out rural economic development. Of course, many types of programs are carried out motivated by other sources, but family planning efforts around the world contribute to the development of the mindset that large and beneficial endeavors are feasible and desirable. ${ }^{3}$ The role of health workers and family support for couples of childbearing age or Pasangan Usia Subur (PUS) is optimal but awareness in PUS must be able to know about the benefits of attending birth so that PUS can overcome the number and distance of children in the family. ${ }^{4}$

There are five policies that Badan Kependudukan dan Keluarga Berencana Nasional (BKKBN) or institutions that control programs related to the use of acceptors in family planning services has taken to anticipate baby booms during the Covid-19 pandemic, one of which is working with midwives to support the distribution of contraceptives and invites private midwifery practice to act as supervisors and leaders in the distribution of contraceptives by family counselors or fieldwork. This was done to expand the area of contraception spread. Most people get family planning services at the midwife. With this partnership, it is expected that the number of family planning users will increase. With the steps and strategies taken by the $\mathrm{BKKBN}$, it is hoped that it can reduce the number of contraceptive discontinuation and can prevent unwanted pregnancies in the future. ${ }^{5}$

An increase in pregnancy rates has a long-standing impact, ranging from the swelling of costs incurred by the state to the increased potential for maternal and infant mortality. There is a clear relationship between various pregnancy disorders and the long-term effects on maternal health. Women with a history of poor pregnancy increase their risk of cardiovascular disease and metabolism later in life. ${ }^{6}$ The maternal and infant mortality rates during childbirth are important indicators in the public health sector of a nation. One of the actions in question is by cooperating with related parties, namely by prioritizing family planning services, namely midwives. ${ }^{5}$ 
Midwives have authority based on Permenkes No. 28 of 2017 concerning licensing and implementation of midwife practices in which midwives have authority in family planning services. ${ }^{7}$ During this pandemic, midwives can provide education and counseling directly while still paying attention to self-protection or through online media (SMS, telephone, or WhatsApp). If the community comes to the midwife, they must first make an appointment in order to be ready to serve and prevent them by using personal protective equipment.

Based on the 2013 Riskesdas data, there were $76.6 \%$ of family planning services performed by midwives and $54.6 \%$ of total family planning services by midwives received services at private midwifery practice. ${ }^{8}$ The number of private midwifery practice in Indonesia is 40,000 private midwifery practice. The phenomenon that develops in the current situation is predicted to be a reduction in community visits to health facilities, including private midwifery practice. ${ }^{9}$ This phenomenon is certainly closely related to active family planning participants and new family planning participants who want to get family planning services through local health facilities. ${ }^{10}$

Looking at the picture of family planning services at private midwifery practice can be one of the benchmarks for predicting a decrease in contraceptive use that can trigger a baby boom in the future ${ }^{11,12}$. It is hoped that strategic efforts can be made to anticipate a baby boom where midwives can play an active role in prevention efforts. The purpose of this study was to analyze family planning service visits at the private midwifery practice in Yogyakarta

\section{Method}

This type of research is descriptive observational quantitative research. The population in this study are 350 midwives in private midwifery practice in Yogyakarta. The sample of this study is midwives who have private midwifery practice in Yogyakarta who meet the inclusion and exclusion criteria of 50 respondents, but there were 3 samples that dropped out of the study because not registered in BKKBN data. Inclusion criteria in this study are midwives who have private midwifery practice that registered in BKKBN. The exclusion criteria (criteria where the research subject can not represent a sample because it does not qualify as a sample research) in this study were midwives whose private midwifery practice were closed during the covid-19 pandemic, midwives did not provide Family Planning services during the Covid-19 pandemic period and midwives had not submitted on the google research form until the specified time. The sampling technique used accidental sampling. The research instrument used a questionnaire in the form of Google at the link (https://forms.gle/PxjyGBTS9DFyzLeW9) containing the identity of midwives, questions about family planning visits based on each contraceptive method and questions about family planning protocols during the Covid-19 pandemic. The data obtained were analyzed using univariate analysis by showing 
a frequency distribution table. Google form distribution was done through WhatsApp Group private midwifery practice in the Yogyakarta.

\section{Results}

This study used 50 research samples and during the data collection, there were 3 samples that dropped out of the study. Private midwifery practice locations that were successfully submitted on Google Form can be seen from table 1.

Table 1. Privat Midwifery Practice Location Distribution (N: 47)

\begin{tabular}{lcc}
\hline $\begin{array}{c}\text { Private midwifery practice / } \\
\text { Clinic Location }\end{array}$ & Amount & Percentage \\
\hline Yogyakarta City & 14 & $29.7 \%$ \\
Sleman Regency & 18 & $38.3 \%$ \\
Bantul Regency & 10 & $21.3 \%$ \\
Kulon Progo Regency & 4 & $8.5 \%$ \\
Gunung Kidul Regency & 1 & $2.2 \%$ \\
\hline Total & 47 & $100 \%$ \\
\hline
\end{tabular}

From the distribution of locations, it can be seen that geographical conditions can be a factor in the ease of accessing the internet. Private midwifery practice, which is located in Sleman Regency, Yogyakarta City, and Bantul Regency, is the most filled in Google form, one of the factors because geographical conditions make it easy to access the internet. Some private midwifery practices that dropped out of the study were caused by not opening services during the Covid-19 pandemic.

Table 2. Data on family planning services based on contraceptives provided by midwife respondents at Private Midwifery Practice in Yogyakarta during Covid-19 pandemic (from February to March 2020)

\begin{tabular}{lll}
\hline Contraception Visit & Amount & Percentage \\
\hline Mini pill and Combination Pills & 24 & \\
Decrease & 23 & $51.1 \%$ \\
Did not decrease & & $48.9 \%$ \\
1 Month Injections & 24 & \\
Decrease & 23 & $51.1 \%$ \\
Did not decrease & & $48.9 \%$ \\
Change the method of injection 1 to 3 months & 13 & $27.7 \%$ \\
Yes & 34 & $72.3 \%$ \\
No & & \\
3-month injection & 21 & $44.7 \%$ \\
Decrease & 26 & $55.3 \%$ \\
Did not decrease & & \\
IUD/ AKDR & 29 & $61.7 \%$ \\
Decrease & 18 & $38.3 \%$ \\
Did not decrease & & \\
Implant/ AKBK & 25 & $53.2 \%$ \\
Decrease & 22 & $46.8 \%$ \\
Did not decrease & & \\
\hline
\end{tabular}


The types of contraception served at private midwifery practice during the covid pandemic 19 that took place from March to April 2020 that all types of contraceptive methods are served at private midwifery practice. In accordance with the authority of midwives in Permenkes 28 of 2017, midwives have the authority in providing family planning services with various contraceptive methods such as pills, injections, intrauterine device (IUD), subcutaneous contraception (AKBK), and condoms.

Based on table 2, it can be seen that the contraceptive or family planning services at private midwifery practice during the Covid-19 pandemic that experienced the most decline were the IUD or IUD contraceptive method in which $61,7 \%$ had decreased from February to March 2020. This data is obtained from the visit report of each PMB that has filled the google form. Contraception services using mini pill reduced by 24 private midwifery practice or $51,1 \%$. The visit of contraceptive services using 1-month injection decreased at 24 private midwifery practices or $51,1 \%$. The visit of contraceptive services using 3-month injection decreased at 21 private midwifery practice or $44,7 \%$. At the visit with implantation services using implants there was a decrease in 25 private midwifery practice or $53,2 \%$.

\section{Table 3. Overview of Implementation of the Contraceptive Services Protocol} during the COVID-19 Pandemic Period

\begin{tabular}{lll}
\hline Service Protocol & Amount & Percentage \\
\hline Midwives make online service agreements & 31 & $68 \%$ \\
Yes & 16 & $32 \%$ \\
Not & & \\
Midwives conduct IEC and online family planning consultations (via & & $78.7 \%$ \\
WA, SMS, Video call and by phone) & 37 & $21.3 \%$ \\
Yes & 10 & \\
Not & & $44.7 \%$ \\
Midwives perform post-placental IUD birth control services & 22 & $55.3 \%$ \\
Yes & 25 & \\
Not & & $97.9 \%$ \\
Midwives ask family planning acceptors to wear masks and wash their & & $2.1 \%$ \\
hands before \& after entering the service room & 46 & \\
Yes & 1 & $78.7 \%$ \\
Not & & $21.3 \%$ \\
Midwives use standard level 1 PPE plus a face shield when performing \\
Yentraceptive services & & \\
Not & 37 & 10 \\
\hline
\end{tabular}

Based on table 3 it can be seen that the service protocol carried out by private midwifery practice during the Covid-19 period in which midwives had carried out family planning service standards including $68 \%$ of midwives made online service agreements namely $78,7 \%$ of midwives did teleconsultation where communication, information, education, and consultation family planning is done online either by SMS, telephone or whatsapp.

From table 3, it can also be seen that midwives have also carried out an infection prevention protocol by applying rules for using masks both clients and midwives as providers and providing 
handwashing facilities to be used before and after being in private midwifery practice. As many as $78,7 \%$ of midwives have also used the minimum standard of personal protective equipment in family planning services, namely the minimum standard of personal protective equipment at level 1 consisting of head coverings, masks, work clothes, gloves, and covered footwear plus face shields as prevention of droplet and aerosol exposure which is one of the main ways of spreading Covid-19.

Based on table 3 that only $44,7 \%$ of midwives provide family planning services for post placental IUDs, which are the main contraceptive method recommended for post partum contraception especially, during the Covid-19 pandemic. Post placenta IUDs can be contraceptives which can be the choice of long-term contraceptive methods, after which installation can be postponed if there are no complaints, thus minimizing contact with health workers but not dropping out of family planning. Counseling about the post placenta IUD method performed since pregnancy involving the husband can increase the willingness and stability of the acceptor using a post placenta IUD. ${ }^{13}$ Post placenta IUDs are an effective method because patients immediately use contraception after they do not need to go to the facility for family planning at intervals after the puerperium. So that it can further reduce contact or reduce service directly because it does not have to go to the midwife continuously in the near future. Counseling during the Covid-19 period can be done through telek counseling using online media.

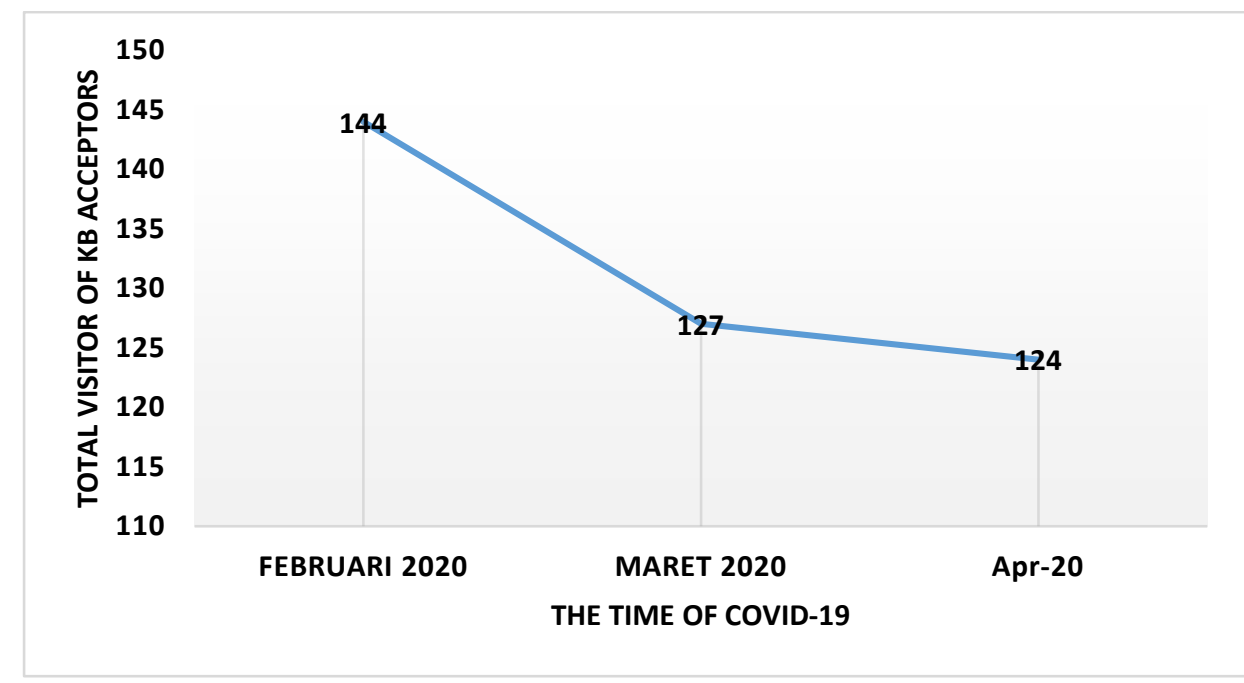

\section{Picture 1. Graph of Family Planning Service Level by Private Midwife Practice During the COVID-19 Pandemic Period}

Based on the graph above it is known that the number of family planning service visits to private midwifery practice has decreased before the occurrence of the Covid-9 pandemic in Indonesia, with a range of average decline in family planning visits at private midwifery practice around 13,8\% (from February until April 2020). The description of family planning services in private midwifery practice 
can be one indicator of success the family planning services in Indonesia, because based on family planning services, $23.61 \%$ is conducted in private midwifery practice ${ }^{14}$. The decline in family planning acceptor visits at private midwifery practice during the Covid-19 pandemic can be a prediction of a baby boom in the future. Based on the data obtained, an average decline in family planning service visits at private midwifery practice during the Covid-19 pandemic. In this study showed a decrease in family planning visits by midwives in the practice of independent midwives from 144 visits in February, then decreased to 127 visits in March and decreased in April.

\section{Discussion}

By predictions made by the United Nations Population Fund (UNFPA), where the impact of Covid-19 can hamper family planning services including the closure of health facilities including private midwifery practice, health workers focus on handling Covid-19 to the rule out family planning services, and the supply or availability of equipment contraception is limited during the pandemic. ${ }^{15}$

This relates to family planning service guidelines during the Covid-19 pandemic, that IUD acceptors that expire if it is not possible to come to a health facility can use condoms that can be purchased alone or obtained from family planning officers in the field or cadres by phone through the cadres $^{2}$. IUD contraception, as besides being effective contraception, does not interfere with breast milk and the data self-checks the position of the IUD itself by ensuring the thread is in the cervix every month after menstruation. It becomes one of the factor in reducing IUD family planning acceptor visits in addition to fear of acceptors accessing family planning services in health facilities, including private midwifery practice ${ }^{15}$. This has become a factor in the decline in IUD KB acceptor visits in addition to the difficulty of acceptors of access to family planning services in health facilities, including private midwifery practice ${ }^{7}$. It means that it is to decrease the repeat visit or IUD control during a pandemic because the IUD acceptor can exercise independent control by checking the thread on the cervix when menstruation is complete. So that independent control is one of the advantages of IUD contraception.

The impact of the spread of the Covid-19 outbreak in Indonesia that began in March 2020 affected various aspects, including the Family Planning Program service. There was a decrease in family planning participants in March 2020 when compared to February 2020 throughout Indonesia. Data from BKKBN shows the use of IUDs in February 2020 totaled 36,155 to 23,383. While implants from 81,062 to 51,536 , injections from 524,989 to 341,109 , pills 251,619 to 146,767 , condoms from 31,502 to 19,583 , male surgery methods from 2,283 to 1,196 , and female surgery methods from 13,571 to 8,093 . This is not without reason, of course, many family planning acceptors feel scared when they want to access family planning services during the Covid-19 pandemic ${ }^{5}$. The decline in the number of family planning participants can encourage the baby boom in the coming months. Various policies 
have been made by the National Population and Family Planning Agency (BKKBN) to continue increasing the participation of family planning to anticipate future baby booms for the welfare of the community during the Covid-19 pandemic both short and long term. ${ }^{5}$ In this pandemic condition, it is expected that couples of childbearing age, especially in couples of very fertile age based on "4 Too" (4T) that are too young, too close, too much and too old are not expected to become pregnant so that health workers need to ensure they continue to use contraception. ${ }^{16,17}$ In dealing with the Covid-19 pandemic, services are still being carried out but by applying the principles of preventing infection control and physical distancing. ${ }^{2}$

Almost all methods of contraception experienced a decrease in services at private midwifery practice, only the 3-month injection method or family planning injection of progestin did not decrease. Because by using the injection method, the user does not have to go to the midwife every month. This is consistent with BKKBN data that the method of injecting contraception reaches $48,56 \%$ of the total contraceptive methods used by couples of childbearing age or pasangan usia subur (PUS) ${ }^{14}$ Injecting family planning acceptors still have the awareness to use contraception on the schedule of repeat visits and the injection method indeed is very dependent on health workers including midwives at private midwifery practice. Changes from short-term contraceptive methods such as injection of 1 month (family planning with injection method) to injections of 3 months (family planning with progestin) also did not change. ${ }^{18,19,3}$ Whereas the choice of short-term to long-term contraceptive methods can be one of the strategies in minimizing client contact with the provider (midwife) during the Covid-19 pandemic so that it becomes one of the efforts to prevent Covid-19 transmission.

Services related to contraception are carried out by midwives more online, namely by conducting teleconferencing where communication and consultation are carried out online either by SMS, telephone, or WhatsApp. This is done to minimize contact and maintain physical distancing ${ }^{2}$. As many as $97.9 \%$ of midwives have provided a place to wash hands before and after receiving services at a private midwifery practice and ensure family acceptors plan to use masks when they receive services. Data from other studies show that the use of video media information about post placenta IUDs can also be done in the Covid-19 period. The results showed that there was a significant relationship between giving video information to approval $(p=0,026)$ and installation $(p=0,034)$ of post-placental IUDs. ${ }^{10,20}$ Video information influences in increasing the number of pasca plasenta IUD acceptors with a significance value of 0,018 so that if the provision of video information increases, the decision to install an IUD also increases. ${ }^{21}$

The decline in infant and child mortality in Indonesia is not accompanied by a significant reduction in fertility. The high fertility rate contributes to the increasing burden of dependency on young people so that the proportion of the productive age population does not experience a significant 
increase. $^{22}$ Efforts to anticipate and prevent the negative impact of baby booms can be made by increasing coverage of postnatal family planning, especially on the use of long-term contraceptive methods such as post placenta IUDs by midwives because generally during this pandemic the number of deliveries in private midwifery practice increased because people were afraid to give birth at the Primary Health Care and Hospital. Besides, midwives can play an active role by providing education information communication and visiting agreements to acceptors through online media to arrange visit schedules at private midwifery practice so that acceptors can still use contraceptive services at private midwifery practice by minimizing contact time, minimizing the risk of transmission by using personal protective equipment and protecting the physical provoked so that there is no build-up of patients while serving at private midwifery practice.

Baby boom brings two positive and negative impacts for one region and even country. ${ }^{23}$ Like China, Indonesia is a country with a large population. China is predicted to experience a baby boom with the policy of two children from married couples who were born as a result of the one-child policy. The population explosion for the Chinese government is considered to only hurt increasing the burden of public services.

The negative implications of the baby boom are that the pressure created by so many elderly people will shake the market. Every young person will have several parents who are supported in terms of taxes and the cost of social programs. ${ }^{24}$ In Indonesia, due to the Covid-19 pandemic, it has caused an increase in population poverty, the number of workers being laid off so that unemployment has increased. These circles are predicted to have difficulty in meeting their contraceptive needs. Limitations in the availability of contraceptives during the pandemic are also one of the causes of the surge in unwanted births. Based on research by UNFPA, if health service interruptions and lockdown continue to occur within six months due to the Covid-19 pandemic, it is predicted that as many as 47 million women cannot access modern contraception. ${ }^{15}$ The consequence of this is the risk of an unexpected 7 million pregnancies. ${ }^{25}$ It is expected that the knowledge of the results of this research can be taken into consideration in the planning of an area/region program, especially at the local government to take anticipatory steps, in the beginning, to be implemented in programs related to family planning services in the Covid-19 pandemic conditions. The government is expected to provide free facilities to people who will use family planning acceptors such as making free family planning services by midwives in private midwifery practice to attract the orderly community in using family planning. 


\section{Conclusion}

In general, there was a decline in family planning services at private midwifery practice during the Covid-19 pandemic in the Yogyakarta region by 13,8\% from February to April 2020. Especially post placenta IUDs to minimize family planning dropouts and prevent the risk of transmission of Covid-19 because this method is not only effective, acceptors can exercise monthly control independently. Midwives can improve services by communicating information and education and counseling by utilizing online media by applying service protocols according to service standards in the Covid-19 era. Anticipation is made to reduce the predictions of the baby boom due to the pandemic, among others by ensuring the availability of contraceptives by the government, in this case, the BKKBN in health service facilities, including private midwifery practice and family planning service officers by involving health cadres. BKKBN will also issue contraceptives for birth control pills and condoms that are easy for the community to use without having to regularly come to health care facilities and rely on health workers. Another effort by the BKKBN to prevent the baby boom is to issue a call through social media not to become pregnant during the Covid-19 pandemic because of the negative effects that can be caused on the mother and fetus due to the spread of Covid-19.

\section{Acknowledgement}

The authors wish to thank the personnel of the private midwifery practice in Yogyakarta, specially to Health Information and Services Department of Sekolah Vokasi UGM and also FKKMK UGM that always supported for scientific writing.

\section{Funding:}

We have no funding for the reasearch.

\section{Conflict of Interest:}

We have no conflict of interest.

\section{Reference}

1. WHO. WHO Director-General's opening remarks at the media briefing on COVID-19 - 11 March 2020. 2020.

2. Kemenkes. Panduan Pelayanan Keluarga Berencana Dan Kesehatan Reproduksi Dalam Situasi Pandemi Covid 19 [Internet]. 2020. 1-5 p. Available from: http://kesmas.kemkes.go.id/assets/upload/dir_519d41d8cd98f00/files/Panduan-pelayanan-KB- 
dan-Kespro-dalam-situasi-COVID19_1578.pdf

3. Mathai M. The global family planning revolution: three decades of population policies and programmes. Bull World Heal Organ. 2008;86.

4. Peterman A, Potts A, O’Donnell M, Thompson K, Shah N, Oertelt-Prigione S, et al. Pandemics and Violence Against Women and Children [Internet]. Washington, DC; 2020. Report No.: 528. Available from: https:/www.cgdev.org/sites/default/files/pandemics-and-vawg-april2.pdf

5. BKKBN. Antisipasi Baby Boom Pasca Pandemi Covid-19, BKKBN Jalankan Pelayanan KB Dengan Tetap Menjaga Jarak Dan Konseling Melalui Media Online. Siaran Pers No RILIS/54/B4/BKKBN/V/2020. 2020;

6. Neiger R. Long-Term Effects of Pregnancy Complications on Maternal Health: A Review. J Clin Med [Internet]. 2017 Jul 27;6(8):76. Available from: http://www.mdpi.com/20770383/6/8/76

7. Permenkes No 28 Tahun 2017. Ijin dan Penyelenggaraan Praktik Bidan. Indonesia; 2017 p. 148.

8. Kemenkes RI. Riset Kesehatan Dasar; RISKESDAS. Jakarta; 2013.

9. Sodik MA, Nzilibili SMM. The Role Of Health Promotion And Family Support With Attitude Of Couples Childbearing Age In Following Family Planning Program In Health. J Glob Res Public Heal. 2017;2(2):82-9.

10. Nurjasmi E. Pandangan Profesi Bidan Serta Rekomendasi Perbaikan Kebijakan Terkait Belanja Strategis JKN. Jakarta; 2015.

11. Yulisman L. With limited access to birth control, Indonesia set to see a COVID-19 baby boom. The Straits Times/Asia News Network [Internet]. 2020 May 13; Available from: https://www.thejakartapost.com/news/2020/05/13/with-limited-access-to-birth-controlindonesia-set-to-see-a-covid-19-baby-boom.html

12. Mamelund S-E. Can the Spanish Influenza Pandemic of 1918 Explain the Baby Boom of 1920 in Neutral Norway? Popul (English Ed 2002-). 2004;59:229-60.

13. Ariningtyas RE, Joebagio H, Pamungkasari EP. Effectiveness of Counseling on the Willingness to Use Intra-Uterine Device Contraceptive after Placenta Detachment among the Health Insurance Participants in Panembahan Hospital, Bantul. J Heal Policy Manag [Internet]. 2016;01(01):8-12. Available from: http://www.thejhpm.com/index.php?journal=thejhpm\&page=article\&op=view\&path\%5B\%5D= 6\&path $\% 5 \mathrm{~B} \% 5 \mathrm{D}=12$

14. Kemenkes RI. Situasi dan Analisis Keluarga Berencana [Internet]. Jakarta; 2014. Available from: infodatin-kb.pdf 
15. UNFPA, Avenir Health, Johns Hopkins University (USA), Victoria University (Australia). Impact of the COVID-19 Pandemic on Family Planning and Ending Gender-based Violence, Female Genital Mutilation and Child Marriage; Pandemic threatens achievement of the Transformative Results committed to by UNFPA [Internet]. 2020. (Interim Technical Note Information as of 27 April 2020). Available from: https://www.unfpa.org/sites/default/files/resource-pdf/COVID-

19_impact_brief_for_UNFPA_24_April_2020_1.pdf

16. Intrauterine Devices. J Midwifery Womens Health [Internet]. 2018 Jul;63(4):501-2. Available from: http://doi.wiley.com/10.1111/jmwh.12887

17. Doss BD, Rhoades GK, Stanley SM, Markman HJ. The effect of the transition to parenthood on relationship quality: An 8-year prospective study. J Pers Soc Psychol [Internet]. 2009 Mar;96(3):601-19. Available from: http://doi.apa.org/getdoi.cfm?doi=10.1037/a0013969

18. Kusuma N. Relationship Between Method and Duration of Contraception Usage to Subjective Health Complaints. J Berk Epidemiol [Internet]. 2017 Feb 5;4(2):164. Available from: https://ejournal.unair.ac.id/JBE/article/view/2154

19. Aryati S, Sukamdi S, Widyastuti D. Faktor-Faktor Yang Mempengaruhi Pemilihan Metode Kontrasepsi (Kasus Di Kecamatan Seberang Ulu I Kota Palembang). Maj Geogr Indones [Internet]. 2019 May 22;33(1):79. Available from: https://journal.ugm.ac.id/mgi/article/view/35474

20. Gugus Tugas Percepatan Penanganan Covid-19. Standar Alat Pelindung Diri (APD) untuk Penanganan Covid 19 di Indonesia. Revisi 2. Jakarta; 2020. 1-40 p.

21. Susanty G, Tiro E, Madya F, Sunarno I, Tahir M, Tessy T. Informatic Video Increased The Number of Acceptors in Post Placenta Insertion of Intrauterine Device (IUD). Indones J Obstet Gynecol [Internet]. 2019 Oct 30;292-5. Available from: http://inajog.com/index.php/journal/article/view/1083

22. Andriani DS, Pitoyo AJ, Pangaribowo EH. Ketidaktercapaian Bonus Demografi: Pembelajaran dari Sumatera Barat. Populasi [Internet]. 2018 Sep 12;26(1):1. Available from: https:/jurnal.ugm.ac.id/populasi/article/view/38685

23. Kazuo Y. The Effect of the Baby Boomer Generation on Japan. JAPAN SPOTLIGHT. 2005; November/D:10-1.

24. Zeng Y, Hesketh T. The effects of China's universal two-child policy. Lancet [Internet]. 2016 Oct;388(10054):1930-8. Available from: https://linkinghub.elsevier.com/retrieve/pii/S0140673616314052

25. Puspa A. Atasi Ancaman Baby Boom. 2020; Available from: 
Herawati et al. / Jurnal Ilmu Kesehatan Masyarakat, July 2020, 11 (2):123- 135

https://mediaindonesia.com/read/detail/310521-atasi-ancaman-baby-boom. 